\title{
Control of cucumber (Cucumis sativus L.) tolerance to chilling stress - evaluating the role of ascorbic acid and glutathione
}

\author{
Alexander S. Lukatkin ${ }^{1 *}$ and Naser A. Anjum ${ }^{2}$ \\ ' Department of Botany, Physiology and Ecology of Plants, N.P. Ogarev Mordovia State University, Saransk, Russia \\ ${ }^{2}$ CESAM-Center for Environmental and Marine Studies and Department of Chemistry, University of Aveiro, Aveiro, Portugal
}

Edited by:

Adriano Sofo, Università degli Studi della Basilicata, Italy

\section{Reviewed by:}

Sarvajeet Singh Gill, Maharshi

Dayanand University, India

Yogesh Abrol, Bhagalpur University, India

\section{*Correspondence:}

Alexander S. Lukatkin, Department of Botany, Physiology and Ecology of Plants, N.P. Ogarev Mordovia

State University, Bolshevistskaja Str., 68. Saransk 430005, Russia e-mail: aslukatkin@yandex.ru
Chilling temperatures $\left(1-10^{\circ} \mathrm{C}\right)$ are known to disturb cellular physiology, cause oxidative stress via creating imbalance between generation and metabolism of reactive oxygen species (ROS) leading finally to cell and/or plant death. Owing to known significance of low molecular antioxidants-ascorbic acid (AsA) and glutathione (GSH) in plant stress-tolerance, this work analyzes the role of exogenously applied AsA and GSH in the alleviation of chilling stress $\left(3^{\circ} \mathrm{C}\right.$ )-impact in cucumber (Cucumis sativus L. cv. Vjaznikowskij 37) plants. Results revealed AsA and GSH concentration dependent metabolism of ROS such as superoxide $\left(\mathrm{O}_{2} \bullet^{-}\right)$and the mitigation of ROS-effects such as lipid peroxidation (LPO) as well as membrane permeability (measured as electrolyte leakage) in C. sativus leaf discs. AsA concentration $(750 \mu \mathrm{M})$ and GSH $(100 \mu \mathrm{M})$ exhibited maximum reduction in $\mathrm{O}_{2} \bullet^{-}$generation, LPO intensity as well as electrolyte leakage, all of these were increased in cold water $\left(3\right.$ and $\left.25^{\circ} \mathrm{C}\right)$-treated leaf discs. However, AsA, in particular, had a pronounced antioxidative effect, more expressed in case of leaf discs during chilling $\left(3^{\circ} \mathrm{C}\right)$; whereas, at temperature $25^{\circ} \mathrm{C}$, some AsA concentrations (such as 50 and $100 \mathrm{mM}$ AsA) exhibited a prooxidative effect that requires molecular-genetic studies. Overall, it is inferred that AsA and GSH have high potential for sustainably increasing chilling-resistance in plants.

Keywords: chilling stress, oxidative stress, ascorbic acid, glutathione, Cucumis sativus L., tolerance

\section{INTRODUCTION}

Sub-optimal (low non-freezing/chilling) temperatures are among the major environmental factors known to impact crop productivity via affecting growth, development and metabolism especially in the tropics and subtropics (Lukatkin et al., 2012; Li et al., 2014). Plant species may exhibit their differential sensitivity to chilling stress, where the exhibition of their incapability to withstand potential impacts of low temperatures has been extensively reported in chilling-sensitive/ non-tolerant plants (reviewed by Lukatkin et al., 2012). At temperatures above the freezing point of tissues but lower than $10^{\circ} \mathrm{C}$ (chilling temperature), a range of chilling-sensitive crop plants (such as maize, rice, cotton, tomato, cucumber, and soybeans) may develop external symptoms of injury and/or may succumbed to death (reviewed by Lukatkin et al., 2012). In chilling-sensitive plants, visible symptoms of injury may include wilting leaves and hypocotyls, the appearance of surface pits and large cavities, discoloration of leaves and internal tissues, and leaf necrosis and plants death (Tsuda et al., 2003; reviewed by Lukatkin et al., 2012). At cellular level, chilling-sensitive plant genotypes may exhibit: impaired cell cycle progression (Rymen et al., 2007), multiple disorganizations of the cells' ultrastructure, such as disturbed the formation of chloroplasts, caused destruction of chloroplasts membranes (Gutierrez et al., 1992; Kratsch and Wise, 2000), shift in intracellular pH, and an increase in cell membrane permeability (Kasamo et al., 2000; reviewed by Lukatkin et al., 2012).
Oxidative stress, a physiological condition, where occurs an imbalance between the generation of reactive oxygen species (ROS; such as singlet oxygen, ${ }^{1} \mathrm{O}_{2} \bullet^{-}$; superoxide anion, $\mathrm{O}_{2} \bullet^{-}$; hydroxyl radical, $\mathrm{HO}^{\bullet}$; hydrogen peroxide, $\mathrm{H}_{2} \mathrm{O}_{2}$ ) and their and metabolism via enzymatic and non-enzymatic antioxidants, may also occur in chilling-sensitive plants (Lukatkin, 2002a,b; Xiong et al., 2002; Gill and Tuteja, 2010; Anjum et al., 2012). Non-metabolized ROS may cause considerable damages to membrane lipids (lipid peroxidation, LPO) and other cellular components, and also increase electrolyte leakage (Lukatkin, 2003; Suzuki and Mittler, 2006; Anjum et al., 2010, 2012, 2014a; Gill and Tuteja, 2010; Popov et al., 2010). To efficiently counteract ROS-mediated potential consequences, plants employ enzymatic (SOD, superoxide dismutase; CAT, catalase; GPX, guaiacol peroxidase; GST, glutathione sulfo-transferase; APX, ascorbate peroxidase; MDHAR, monodehydroascorbate reductase; DHAR, dehydroascorbate reductase; GR, glutathione reductase) and non-enzymatic (ascorbic acid, AsA; glutathione, GSH; carotenoids; tocopherols; phenolics) antioxidants-based defense system (Anjum et al., 2010, 2012, 2014b; Gill and Tuteja, 2010).

Though the role of AsA and GSH in plant stress-tolerance has been emphasized (Anjum et al., 2010; Noctor et al., 2012), and the literature is full on the significance of AsA (Dolatabadian et al., 2008; Kumar et al., 2011b; Zhang et al., 2011), and also that of GSH (Anjum et al., 2010; Cai et al., 2010), reports on a comparative account of AsA and GSH in chilling exposed plants 
are rare and/or unsubstantiated. Therefore, this work analyzes the role of exogenously applied AsA and GSH in the alleviation of chilling stress-impact in cucumber (Cucumis sativus L. cv. Vjaznikowskij 37) plants.

\section{MATERIALS AND METHODS PLANT CULTURE AND TREATMENTS}

Cucumber (Cucumis sativus L. cv. Vjaznikowskij 37) seeds were surface sterilized with $0.5 \% \mathrm{KMnO}_{4}$ for $20 \mathrm{~min}, 6 \%$ chloramines for $10 \mathrm{~min}$ and $70 \%$ ethanol for $1 \mathrm{~min}$ then rinsed with sterile water. Sterilized seeds were sown in pots containing $2.0 \mathrm{~kg}$ of soil (median-loamy degraded chernozem) at $22-24^{\circ} \mathrm{C}, 60-80 \%$ of full soil water capacity, and with illumination about $200 \mu \mathrm{M}$ photons $\mathrm{m}^{-2} \mathrm{~s}^{-1}$ ) photosynthetic photon flux density (PPFD) and $12 \mathrm{~h}$ light day. Leaves were isolated from 18 to 20 day old plants and leaf discs ( $8 \mathrm{~mm}$ in diameter) were punched with a cork-borer. Subsequently, leaf discs were immersed in Petri dishes (about $300 \mathrm{mg}$ leaves discs per $10 \mathrm{ml}$ of water or antioxidant solution (AsA: 0.5, 0.75, 1.5, 10, 50, $100 \mathrm{mM}$; or GSH: 50, 100, $150 \mu \mathrm{M}$ ), all with temperature 25 or $3^{\circ} \mathrm{C}$ ) and kept from 0.5 to $2 \mathrm{~h}$ at these temperatures. The control leaf discs were kept at $25^{\circ} \mathrm{C}$.

\section{BIOASSAYS}

The methods adopted and described by Lukatkin (2002a) were employed to estimate $\mathrm{O}_{2} \bullet-$ generation (based on oxidation of adrenaline), and membrane lipid peroxidation (LPO) (measured as the level of MDA). In brief, homogenate obtained by the homogenization of leaf discs $(0.3 \mathrm{~g})$ in distilled was centrifuged for $15 \mathrm{~min}$ at $4000 \mathrm{~g}$. To $3.0 \mathrm{ml}$ of supernatant, $100 \mu \mathrm{l}$ of $0.01 \%$ adrenaline (epinephrine) solution was added, and the tube was incubated for $45 \mathrm{~min}$ at room temperature and $80 \mu \mathrm{M}$ photons $\mathrm{m}^{-2} \mathrm{~s}^{-1}$ PPFD. Immediately at the end of incubation, optical density of the adrenochrome formed (as a measure of estimate $\mathrm{O}_{2} \bullet^{-}$) was read against homogenate with water on a UVvisible spectrophotometer (SF-46, LOMO, St. Petersburg, Russia) at $480 \mathrm{~nm}$. For LPO estimation, $10 \mathrm{ml}$ of isolation medium (0.1 M Tris- $\mathrm{HCl}$ buffer $\mathrm{pH} 7.6$, containing $0.35 \mathrm{M} \mathrm{NaCl})$ was used to homogenize leaf discs $(1.0 \mathrm{~g})$. To $3.0 \mathrm{ml}$ of the obtained homogenate, $2.0 \mathrm{ml}$ of thiobarbituric acid (TBA) (prepared in $20 \%$ trichloracetic acid, TCA) was added, and the solution was heated in a boiling water bath for $30 \mathrm{~min}$, filtered and ice-cooled and centrifuged at $1000 \times \mathrm{g}$ for $10 \mathrm{~min}$ at $4^{\circ} \mathrm{C}$. Reading in the supernatant was recorded at $532 \mathrm{~nm}$ in the UV-Vis spectrophotometer. The rate of LPO was expressed as $\mu$ mole MDA $g^{-1}$ tissue wet weight using a molar extinction coefficient of $1.56 \times 105 \mathrm{M}^{-1}$ $\mathrm{cm}^{-1}$. Additionally, index of chilling injury (ICI) was assessed by measuring electrolyte leakage employing the formula: Injury cofficient $=\mathrm{Ld}-\mathrm{Lo} / 100-$ Lo $\times 100$ (Lukatkin, 2003). Where, Ld and Lo denote electrolyte losses, respectively from damaged/treated and untreated/control leaf discs. Injury cofficient reflects the electrolyte efflux and was expressed in percent of total loss.

\section{STATISTICAL ANALYSES}

All experiments were repeated three-six times in 4-6 biological replicates. The figures and tables represent the means of all experimental data and their standard errors. The significance of differences between treatments was evaluated by Student's $t$-test.

\section{RESULTS}

The results presented below describe the significant responses of $\mathrm{O}_{2} \bullet-$ generation, LPO and electrolyte leakage considering AsA followed by GSH in chilling experiments with leaf discs.

\section{SUPEROXIDE ION STATUS IN LEAF DISCS UNDER TEMPERATURE REGIMES (25 AND $3^{\circ} \mathrm{C}$ ), AND WITH ASCORBIC ACID AND GLUTATHIONE}

The pattern of AsA effect on $\mathrm{O}_{2} \bullet^{-}$generation exhibited its dependency on AsA concentration and temperature regimes (Table $\mathbf{1}$ ). Leaf discs incubated in the distilled water at $25^{\circ} \mathrm{C}$ showed a monotonous increase of $\mathrm{O}_{2} \bullet^{-}$generation, indicating a graduate intensification of oxidative stress induced by mechanical injuries in leaf disc cells. Though $\mathrm{O}_{2} \bullet^{-}$generation in the leaf disc immersed in AsA solutions at $25^{\circ} \mathrm{C}$ was enhanced too but almost all concentrations of AsA exhibited their tendency to lowering of $\mathrm{O}_{2} \bullet^{-}$generation when compared with leaf discs immersed in water. The best mitigating effect of AsA on $\mathrm{O}_{2} \bullet-$ was with

Table 1 | Effect of ascorbic acid (AsA) concentrations on $\mathrm{O}_{2} \bullet^{-}$generation $\left(\mu \mathrm{M} \mathrm{g}^{-1} \mathrm{~min}^{-1}\right)$ in the leaf discs of Cucumis sativus at 3 and $25^{\circ} \mathrm{C}$ temperatures.

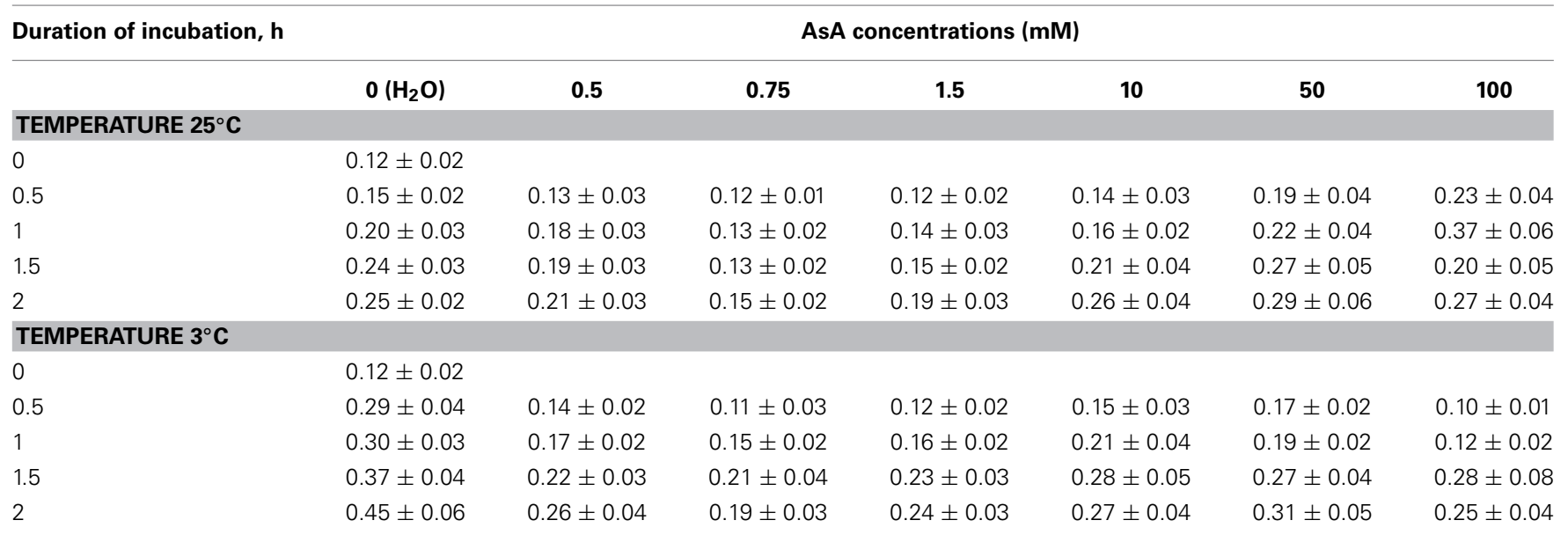


$750 \mu \mathrm{M}$ AsA solution, where a reduction of $40 \%$ in the $\mathrm{O}_{2} \bullet^{-}$ level was evidenced. However, a comparison among the used AsA concentrations revealed a prooxidative effect of the highest AsA concentrations (50 and $100 \mathrm{mM}$ ). On the other hand, incubation of leaf discs in water at $3^{\circ} \mathrm{C}$ lead to more intensive increase of $\mathrm{O}_{2} \bullet^{-}$generation as compared with temperature $25^{\circ} \mathrm{C}$. The rate of $\mathrm{O}_{2} \bullet-$ generation was most prominent after $2 \mathrm{~h}$ of immersion of leaf discs in cold water, where increase of 3.75 times was noted when compared to initial point. Here also, all the used AsA concentrations lead to diminishing of oxidative stress caused by $\mathrm{O}_{2} \bullet-$ elevation when compared with distilled water. Among the AsA concentrations used, $0.75 \mathrm{mM}$ AsA exhibited the highest $\mathrm{O}_{2} \bullet^{-}$-decreasing effect. Interestingly, the highest concentration of AsA ( $100 \mathrm{mM})$ had the best effect in first 0.5 and $1 \mathrm{~h}$ of chilling, with sharp increase of $\mathrm{O}_{2}^{-}$generation in next hour.

Experiments considering another non-enzymatic antioxidant-GSH, showed different pattern of $\mathrm{O}_{2} \bullet^{-}$generation (Figure 1). Here also, leaf discs incubated in the water with $25^{\circ} \mathrm{C}$, as at $3^{\circ} \mathrm{C}$ temperatures exhibited an enhanced rate of $\mathrm{O}_{2} \bullet^{-}$generation, where all the used GSH concentrations effectively lowered the $\mathrm{O}_{2} \bullet-$ generation rate almost similarly at both 25 and $3^{\circ} \mathrm{C}$. Notably, GSH at $100 \mu \mathrm{M}$ most effectively lowered $\mathrm{O}_{2} \bullet^{-}$generation rate when comparison was made among the used GSH concentrations. In the experiments, where leaf discs were incubated for $4 \mathrm{~h}$ in solutions with different GSH concentrations, $100 \mu \mathrm{M}$ GSH was found as the most effective GSH concentration in decreasing the $\mathrm{O}_{2} \bullet-$ generation rate (Figure 2).

\section{ELECTROLYTE LEAKAGE AND LIPID PEROXIDATION STATUS IN LEAF DISCS WITH ASCORBIC ACID AND GLUTATHIONE}

Electrolyte leakage from leaf discs was used as criterion of cell membrane damage (Figure $2 \mathrm{~B}$ ). At $25^{\circ} \mathrm{C}$, incubation of $C$. sativus leaf discs in AsA solution lead to lowering of electrolyte leakage, but GSH enhanced this parameter. Leaf discs incubated at $3^{\circ} \mathrm{C}$ showed a significant increase in the electrolyte leakage when compared to leaf discs incubated in distilled water. The lowest electrolyte leakage was revealed in the case of AsA and $\mathrm{GSH}$-supplemented solutions. Considering $\mathrm{LPO}$, a $3^{\circ} \mathrm{C}$ caused a significant increase in leaf disc-LPO level (measured as MDA content) when compared to LPO in leaf discs incubated at $25^{\circ} \mathrm{C}$ (Figure 2A). However, leaf discs incubated in antioxidant solution at $25^{\circ} \mathrm{C}$ exhibited a lower LPO intensity, where decreases of 7.8 and $18.8 \%$ were displayed, respectively with GSH and AsA.

\section{DISCUSSION}

The current test plant, C. sativus is a warm-season vegetable and is known for its susceptibility to low temperatures throughout its growth cycle (Kuk and San Shin, 2007). Therefore, this study was performed to assess the role of major non-enzymatic antioxidants such as AsA and GSH in the control of $\mathrm{O}_{2} \bullet-$ generation and its consequence (measured herein as LPO and electrolyte leakage). In the present study, temperature regimes $\left(3\right.$ and $25^{\circ} \mathrm{C}$ ) without AsA or GSH differentially impacted leaf discs by significantly enhancing the content of $\mathrm{O}_{2} \bullet-$ when compared with the control leaf discs. Nevertheless, a gradual time-dependent intensification of oxidative stress (in terms of elevated $\mathrm{O}_{2} \bullet^{-}$generation) was perceptible when incubation of leaf discs was done in water at $3^{\circ} \mathrm{C}$ (vs. $25^{\circ} \mathrm{C}$ ). The detailed above observation coincides well with the earlier studies where, chilling stress enhanced the generation of ROS (such as superoxide, $\mathrm{O}_{2}$.) (Lukatkin, 2002a,b, 2003; Popov et al., 2010). Low temperature-mediated differential enhancements in the generation of $\mathrm{O}_{2}^{-}$have been evidenced earlier in the leaves of a number of plants including cucumber, maize and millet (Lukatkin, 2002a). If not metabolized, ROS

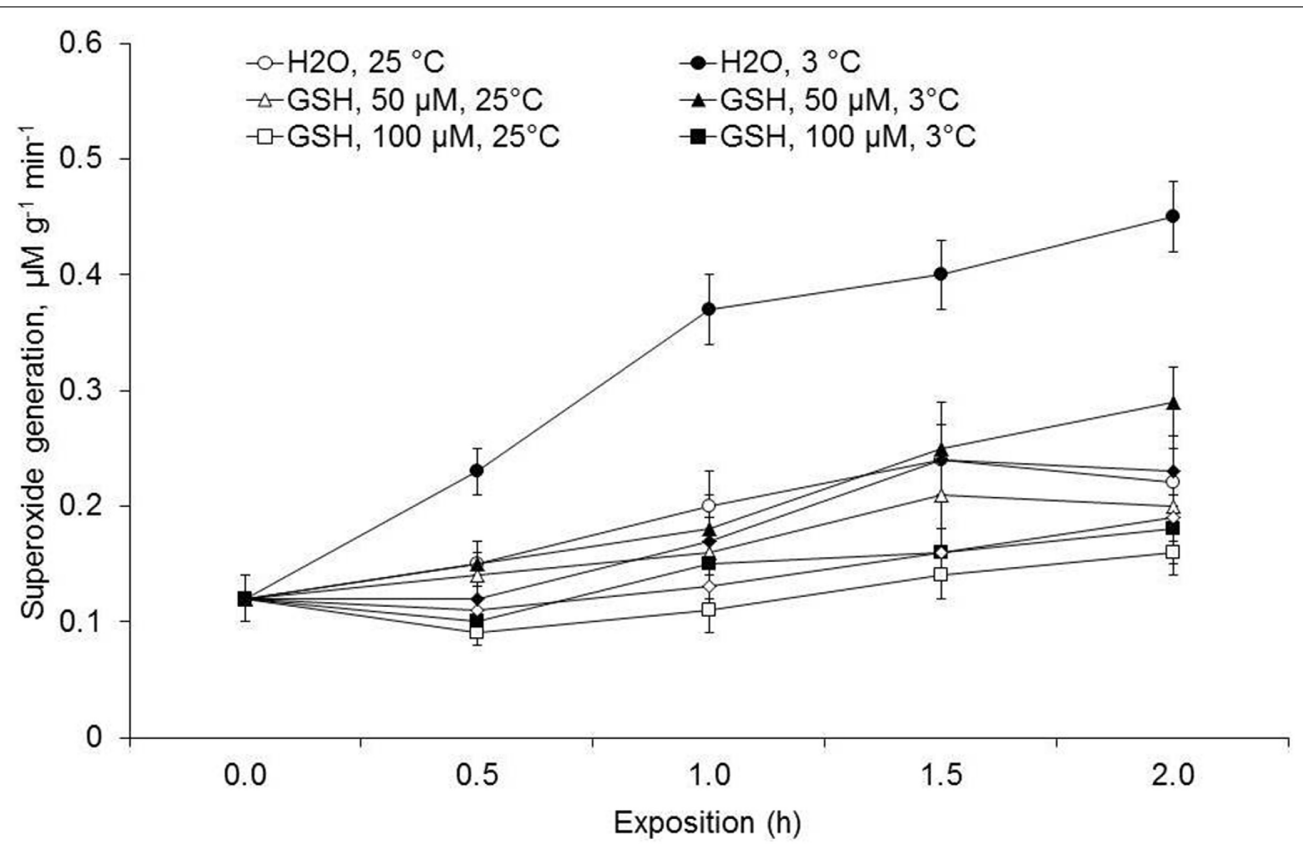

FIGURE 1 | Effects of glutathione (GSH) concentrations on rate of $\mathrm{O}_{2} \bullet^{-}$generation in the leaf discs of Cucumis sativus at 3 and $25^{\circ} \mathrm{C}$ temperatures. 


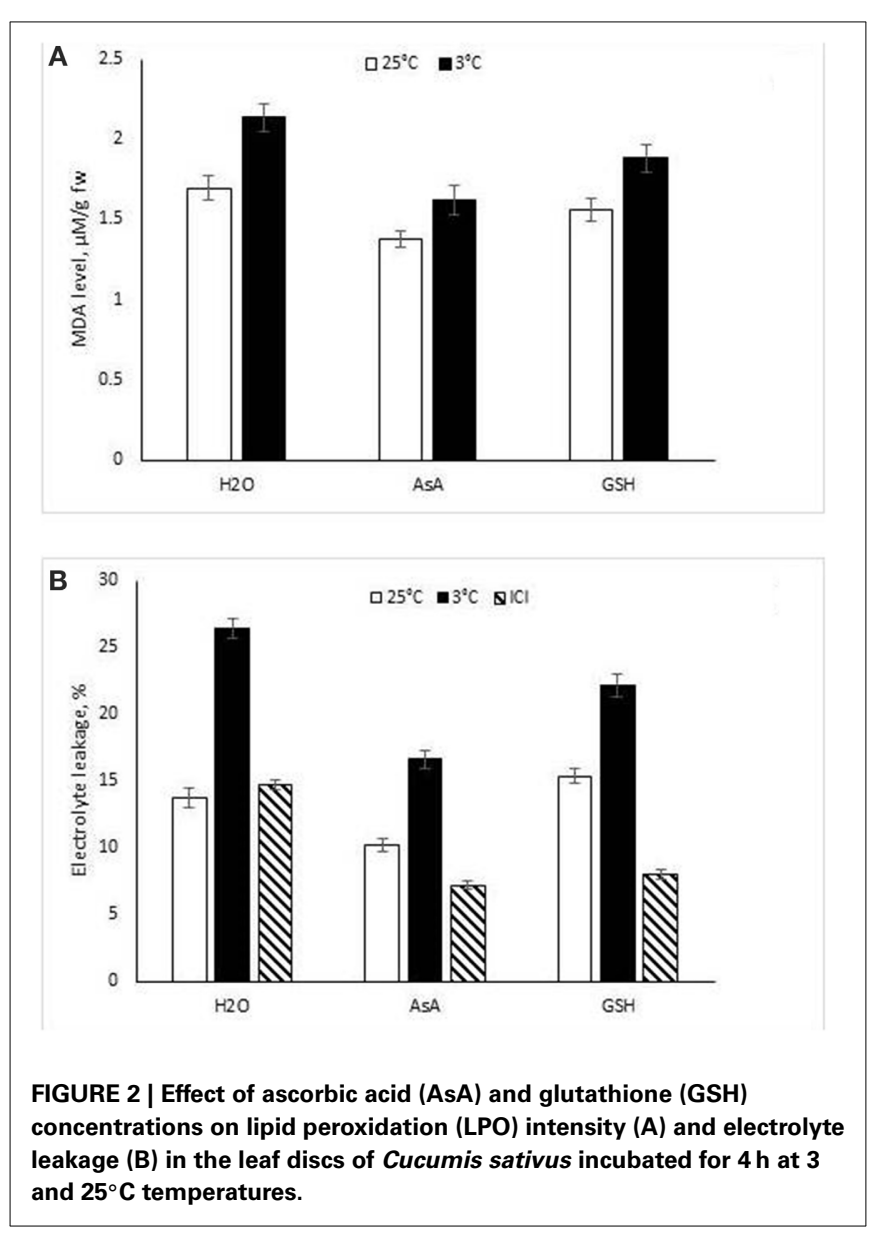

can initiate damaging cellular membrane by oxidizing membrane biomolecules such as lipids and proteins (Anjum et al., 2010, 2012, 2014a; Gill and Tuteja, 2010; Popov et al., 2010; Lukatkin et al., 2012). To this end, electrolyte leakage and lipid peroxidation are among the major consequences of $\mathrm{O}_{2} \bullet-$-accrued impact on cell membrane (Halliwell and Gutteridge, 2000; Anjum et al., 2014a). This is also true in the present study, where leaf discs incubated at $3^{\circ} \mathrm{C}$ exhibited significantly increased electrolyte leakage as well as the content of MDA (a well-known indicator of membrane lipid peroxidation). Nevertheless, enhanced LPO was reported earlier, where the extent of LPO elevation was shown to correlate with species and cultivar sensitivity to chilling, and, therefore, it is believed to be a measure for cold-induced damage to chilling-sensitive plants (Lukatkin, 2002a; reviewed by Lukatkin et al., 2012).

Efficiency of antioxidant defense system to scavenge ROS such as $\mathrm{O}_{2} \bullet$ - largely decides the plant's sensitivity to various stress factors including chilling (Lukatkin, 2002a,b; Xiong et al., 2002; Gill and Tuteja, 2010; Anjum et al., 2012). AsA and GSH are the most abundant low molecular weight non-enzymatic antioxidants in plant cells participating in ROS scavenging (Anjum et al., 2010; Gill and Tuteja, 2010). In the present study, AsA and GSH concentrations differentially controlled the rate of $\mathrm{O}_{2} \bullet-$ generation in the leaf discs incubated in solutions with 3 and $25^{\circ} \mathrm{C}$ temperatures. In particular, AsA concentration $(750 \mu \mathrm{M} ; 0.75 \mathrm{mM})$ and
GSH $(100 \mu \mathrm{M})$ exhibited maximum reduction in the $\mathrm{O}_{2} \bullet^{-}$generation and its consequence measures herein as LPO as well as electrolyte leakage. In fact, apart from the enzymatic antioxidants (such as SOD, CAT, GPX, GST, APX, MDHAR, DHAR, GR), the non-enzymes such as AsA and GSH are among the major nonenzymatic antioxidants significant for efficiently metabolizing major ROS and also for counteracting their consequences (such as electrolyte leakage and LPO) in abiotic stressed plants (Anjum et al., 2010, 2012, 2014b; Gill and Tuteja, 2010). However, AsA, in particular, had a pronounced antioxidative effect, more expressed in case of leaf discs during chilling $\left(3^{\circ} \mathrm{C}\right)$; whereas, at temperature $25^{\circ} \mathrm{C}$, some AsA concentrations (such as 50 and $100 \mathrm{mM}$ AsA) exhibited a prooxidative effect. The observed noticeable result may be a consequence of an interactive effect of exogenous AsA with endogenous $\mathrm{Fe}$ or $\mathrm{Cu}$ (data not shown) that are known to increase of ROS generation via Fenton reaction.

AsA is widely distributed in plant tissues and is used as a substrate by APX (a major ROS-metabolizing enzyme); therefore, reduced AsA significantly controls of the cellular reducing environment (Davey et al., 2000; Anjum et al., 2010, 2014b). Many environmental stresses including chilling conditions can induce an increase of endogenous AsA (Wang et al., 2004). The AsA contents was more in tolerant to chilling stress chickpea (Cicer arietinum) genotypes after chilling at reproductive phase (Kumar et al., 2011a). Overexpression of SIGMEs (Solnaum lycopersicon GDP-Mannose 3',5'-epimerase) was reported to cause AsA accumulation with enhanced cold tolerance in tomato (Zhang et al., 2011). On the other hand, GHS is a crucial antioxidant associated with regenerating AsA in the AsA-GSH cycle, and thus GSH is also involved in the regulation of ROS (such as $\mathrm{H}_{2} \mathrm{O}_{2}$ ) (Anjum et al., 2010). Based on its redox buffering action and abundance in cells, reduced form of GSH is considered to protect the cell against elevated ROS-mediated oxidative damages (Anjum et al., 2010; Noctor et al., 2012). Extensive reports have revealsed that the GSH pool size in plants and the status of its oxidation and reduction are associated highly with plant resistance to stressed environments (Kumar et al., 2008; Xu et al., 2008; Anjum et al., 2010). A differential elevation in GSH has been reported in a number of chilling exposed plants including cucumber genotypes (Xu et al., 2008) and C. arietinum (Kumar et al., 2008). The AsA-GSH cycle is highly related to plant antioxidant defense, and the metabolic intensity of the cycle is directly associated with the capacity of plant resistance to stress. The oxidative and reductive status of AsA and GSH are closely related to the adaptation of plants to stressed environments, and the accomplishment of AsA function depends largely on the available GSH supply and the conditions of oxidation and reduction in cells (Anjum et al., 2010). Lowered extent of oxidative stress and enhanced stress resistance in plants has also been reported with exogenous application (seed treatment, soil influx or foliar spraying) of AsA (Dolatabadian et al., 2008; Dolatabadian and Saleh, 2009; Al-Hakimi and Hamada, 2011; Kumar et al., 2011b) or GSH (Cai et al., 2010; Teh et al., 2014).

\section{CONCLUSIONS}

C. sativus responded to chilling conditions by exhibiting duration of exposure and temperature level-dependent elevations in $\mathrm{O}_{2} \bullet-$ 
and its consequences measured as electrolyte leakage and LPO. Exogenous supply of AsA and GSH to chilling stressed plants can be beneficial in improving plant health and productivity. AsA concentration $(750 \mu \mathrm{M})$ and GSH $(100 \mu \mathrm{M})$ exhibited maximum reduction in the $\mathrm{O}_{2} \bullet^{-}$generation, LPO intensity as well as membrane permeability. It can be said that AsA and GSH have high potential in increase of chilling-resistance in plants. However, molecular-genetic research is required to unveil the exact mechanisms underlying the reported herein peroxidative effect of 50 and $100 \mathrm{mM}$ AsA at temperature $25^{\circ} \mathrm{C}$ that was not displayed at $3^{\circ} \mathrm{C}$.

\section{ACKNOWLEDGMENTS}

Results were obtained in the framework of the state task of the Russian Ministry of Education and Science (project number $6.783 .2014 \mathrm{~K}$, sanctioned to Alexander S. Lukatkin). Naser A. Anjum gratefully acknowledges financial support received from Portuguese Foundation for Science and Technology (FCT) through post-doctoral research grants (SFRH/BPD/64690/2009; SFRH/BPD/84671/2012).

\section{REFERENCES}

Al-Hakimi, A. B. M., and Hamada, A. M. (2011). Ascorbic acid, thiamine or salicylic acid induced changes in some physiological parameters in wheat grown under copper stress. Plant Prot. Sci. 47, 92-108.

Anjum, N. A., Ahamd, I., Mohmood, I., Pacheco, M., Duarte, A. C., Pereira, E., et al. (2012). Modulation of glutathione and its related enzymes in plants' responses to toxic metals and metalloids-a review. Environ. Exp. Bot. 75, 307-324. doi: 10.1016/j.envexpbot.2011.07.002

Anjum, N. A., Gill, S. S., Gill, R., Hasanuzzaman, M., Duarte, A. C., Pereira, E., et al. (2014b). Metal/metalloid stress tolerance in plants: role of ascorbate, its redox couple, and associated enzymes. Protoplasma 251, 1265-1283. doi: 10.1007/s00709-014-0636-x

Anjum, N. A., Sofo, A., Scopa, A., Roychoudhury, A., Gill, S. S., Iqbal, M., et al. (2014a). Lipids and proteins-major targets of oxidative modifications in abiotic stressed plants. Environ. Sci. Pollut. Res. doi: 10.1007/s11356-014-3917-1. [Epub ahead of print].

Anjum, N. A., Umar, S., and Chan, M. T. (2010). Ascorbate-Glutathione Pathway and Stress Tolerance in Plants. Dordrecht: Springer. doi: 10.1007/978-90-4819404-9

Cai, Y., Lin, L., Cheng, W., Zhang, G., and Wu, F. (2010). Genotypic dependent effect of exogenous glutathione on Cd-induced changes in cadmium and mineral uptake and accumulation in rice seedlings (Oryza sativa). Plant Soil Environ. $56,516-525$.

Davey, M. W., Van, M. M., Inze, D., Sanmartin, M., Kanellis, A., Smirnoff, N., et al. (2000). Plant L-ascorbic acid: chemistry, function, metabolism, bioavailability and effects of processing. J. Sci. Food Agric. 80, 825-860. doi: 10.1002/(SICI)1097-0010(20000515)80:7<825::AID-JSFA5 $98>3.0 . \mathrm{CO} ; 2-6$

Dolatabadian, A., and Saleh, J. R. (2009). Impact of exogenous ascorbic acid on antioxidant activity and some physiological traits of common bean subjected to salinity stress. Not. Bot. Horti Agrobot. Cluj-Napoca 37, 165-172.

Dolatabadian, A., Sanavy, S. A. M. M., and Chashmi, N. A. (2008). The effects of foliar application of ascorbic acid (vitamin C) on antioxidant enzymes activities, lipid peroxidation and proline accumulation of canola (Brassica napus L.) under conditions of salt stress. J. Agron. Crop Sci. 194, 206-213. doi: 10.1111/j.1439037X.2008.00301.x

Gill, S. S., and Tuteja, N. (2010). Reactive oxygen species and antioxidant machinery in abiotic stress tolerance in crop plants. Plant Physiol. Biochem. 48, 909-930. doi: 10.1016/j.plaphy.2010.08.016

Gutierrez, M., Sola, M. D., Pascual, L., Rodrigez-Garsia, M. I., and Vargas, A. M. (1992). Ultrastructural changes in cherimoya fruit injured by chilling. Food Struct. 11, 323-332.

Halliwell, B., and Gutteridge, J. M. C. (2000). Free Radicals in Biology and Medicine. Oxford: Oxford University Press.
Kasamo, K., Yamaguchi, M., and Nakamura, Y. (2000). Mechanism of the chillinginduced decrease in proton pumping across the tonoplast of rice cells. Plant Cell Physiol. 41, 840-849. doi: 10.1093/pcp/pcd002

Kratsch, H. A., and Wise, R. R. (2000). The ultrastructure of chilling stress. Plant Cell Environ. 23, 337-350. doi: 10.1046/j.1365-3040.2000. 00560.x

Kuk, Y. I., and San Shin, J. (2007). Mechanisms of low-temperature tolerance in cucumber leaves of various ages. J. Am. Soc. Hortic. Sci. 132, 294-301.

Kumar, S., Kaur, G., and Nayyar, H. (2008). Exogenous application of abscisic acid improves cold tolerance in chickpea (Cicer arietinum L). J. Agron. Crop Sci. 194, 449-456. doi: 10.1111/j.1439-037X.2008.00335.x

Kumar, S., Kaur, R., Kaur, N., Bhandhari, K., Kaushal, N., Gupta, K., et al. (2011b). Heat-stress induced inhibition in growth and chlorosis in mungbean (Phaseolus aureus Roxb.) is partly mitigated by ascorbic acid application and is related to reduction in oxidative stress. Acta Physiol. Plant 33, 2091-2101. doi: 10.1007/s11738-011-0748-2

Kumar, S., Malik, J., Thakur, P., Kaishta, S., Sharma, K. D., Upadhyaya, H. D., et al. (2011a). Growth and metabolic responses of contrasting chickpea (Cicer arietinum L.) genotypes to chilling stress at reproductive phase. Acta Physiol. Plant 33, 779-787. doi: 10.1007/s11738-010-0602-y

Li, Z. G., Zeng, H. Z., Ao, P. X., and Gong, M. (2014). Lipid response to short-term chilling shock and long-term chill hardening in Jatropha curcas L. seedlings. Acta Physiol. Plant 36, 2803-2814. doi: 10.1007/s11738-0141653-2

Lukatkin, A. S. (2002a). Contribution of oxidative stress to the development of cold-induced damage to leaves of chilling-sensitive plants: 1. Reactive oxygen species formation during plant chilling. Russ. J. Plant Physiol. 49, 622-627. doi: 10.1023/A:1020232700648

Lukatkin, A. S. (2002b). Contribution of oxidative stress to the development of cold-induced damage to leaves of chilling-sensitive plants: 2 . The activity of antioxidant enzymes during plant chilling. Russ. J. Plant Physiol. 49, 782-788. doi: 10.1023/A:1020965629243

Lukatkin, A. S. (2003). Contribution of oxidative stress to the development of cold-induced damage to leaves of chilling-sensitive plants: 3 . Injury of cell membranes by chilling temperatures. Russ. J. Plant Physiol. 50, 243-246. doi: 10.1023/A:1022985500733

Lukatkin, A. S., Brazaityte, A., Bobinas, Č., and Duchovskis, P. (2012). Chilling injury in chilling-sensitive plants: a review. Žemdirbystë (Agriculture) 99, $111-124$.

Noctor, G., Mhamdi, A., Chaouch, S., Han, Y. I., Neukermans, J., MarquezGarcia, B. E. L. E. N., et al. (2012). Glutathione in plants: an integrated overview. Plant Cell Environ. 35, 454-484. doi: 10.1111/j.1365-3040.2011. 02400.x

Popov, V. N., Antipina, O. V., and Trunova, T. I. (2010). Lipid peroxidation during low-temperature adaptation of cold-sensitive tobacco leaves and roots. Russ. J. Plant Physiol. 57, 144-147. doi: 10.1134/S1021443710010206

Rymen, B., Fiorani, F., Kartal, F., Vandepoele, K., Inze, D., and Beemster, G. T. S. (2007). Cold nights impair leaf growth and cell cycle progression in maize through transcriptional changes of cell cycle genes. Plant Physiol. 143, 1429-1438. doi: 10.1104/pp.106.093948

Suzuki, N., and Mittler, R. (2006). Reactive oxygen species and temperature stresses: a delicate balance between signaling and destruction. Physiol. Plant 126, 45-51. doi: 10.1111/j.0031-9317.2005.00582.x

Teh, C. Y., Mahmood, M., Shaharuddin, N. A., and Ho, C. L. (2014). In vitro rice shoot apices as simple model to study the effect of $\mathrm{NaCl}$ and the potential of exogenous proline and glutathione in mitigating salinity stress. Plant Growth Regul. doi: 10.1007/s10725-014-9980-2

Tsuda, H., Niimura, Y., and Katoh, T. (2003). Chill injury in Saintpaulia leaf with special reference to leaf spot formation. J. Agric. Sci. Tokyo Nogyo Daigaku. 47, 283-289.

Wang, L. J., Li, S. H., Li, J. Y., Yang, S. H., Liu, Y. F., and Shi, Y. L. (2004). Peroxidation of membrane lipid and calcium distribution in grape mesophyll cells during cross adaptation to temperature stresses. Chinese J. Plant Ecol. 28, 326-332.

Xiong, L., Schumaker, K. S., and Zhu, J. K. (2002). Cell signaling during cold, drought, and salt stress. Plant Cell 14, S165-S183. doi: 10.1105/tpc. 000596

Xu, P. L., Guo, Y. K., Bai, J. G., Shang, L., and Wang, X. J. (2008). Effects of long-term chilling on ultrastructure and antioxidant activity in leaves of 
two cucumber cultivars under low light. Physiol. Plant 132, 467-478. doi: 10.1111/j.1399-3054.2007.01036.x

Zhang, C., Liu, J., Zhang, Y., Cai, X., Gong, P., Zhang, J., et al. (2011). Overexpression of SIGMEs leads to ascorbate accumulation with enhanced oxidative stress, cold, and salt tolerance in tomato. Plant Cell Rep. 30, 389-398. doi: 10.1007/s00299-010-0939-0

Conflict of Interest Statement: The Associate Editor, Adriano Sofo, declares that, despite co-hosting a Frontiers Research Topic with the author, Naser Anjum, the review process was handled objectively and no conflict of interest exists. The authors declare that the research was conducted in the absence of any commercial or financial relationships that could be construed as a potential conflict of interest.
Received: 24 November 2014; accepted: 04 December 2014; published online: 18 December 2014.

Citation: Lukatkin AS and Anjum NA (2014) Control of cucumber (Cucumis sativus L.) tolerance to chilling stress-evaluating the role of ascorbic acid and glutathione. Front. Environ. Sci. 2:62. doi: 10.3389/fenvs.2014.00062

This article was submitted to Environmental Toxicology, a section of the journal Frontiers in Environmental Science.

Copyright $\odot 2014$ Lukatkin and Anjum. This is an open-access article distributed under the terms of the Creative Commons Attribution License (CC BY). The use, distribution or reproduction in other forums is permitted, provided the original author $(s)$ or licensor are credited and that the original publication in this journal is cited, in accordance with accepted academic practice. No use, distribution or reproduction is permitted which does not comply with these terms. 